\title{
THE PARTICIPLE FORM OF CAUSATIVE VERBS IN DANGME
}

\author{
Regina Oforiwah Caesar \\ University of Education, Winneba \\ College of Language Education \\ Department of Ga-Dangme Education \\ P.O.Box 72 Ajumako \\ Ghana \\ reginacaesar16@hotmail.com
}

\section{ABSTRACT}

This paper presents a descriptive analysis of verbs with the participle marking affixes in expressing causatives in Dangme, a language that belongs to the Kwa group of the Niger-Congo family of languages. The paper examines the syntax and the semantic perspectives of the participialized form of causative verbs in the Role and Reference Grammar's (RRG) theory in Dangme. The participle is an affix which expresses the completion at the final stage of a process. As a verbal affix, it can take objects and have tense or aspect in languages. They also indicate active agency (actor) and an agency receiving an action (sufferer). Generally affixes that express participial are in two forms: the finite and non-finite categories. Unlike Akan and other languages that have both forms, Dangme has just the non-finite category which of two forms. The two non-finite forms of the verb in Dangme are the participle and the gerund. The gerund affix $\{-\mathrm{mi}\}$ denotes a new word class from verbs in Dangme, (noun). The participle on the other hand has adjectivelike characteristics and it is expressed mostly with the front vowels of Dangme: /i, e, $\varepsilon /$. It is to be noted that to form the participle in Dangme, two processes are required. Firstly, the verb stem is reduplicated either partially or totally depending on the shape of the verb stem. The reduplicant then selects a front vowel of the same tongue height of the vowel of the verb stem. The words formed imply a process of change caused by a causer. For the purpose of this paper, my focus is on the participial affix used in expressing causative meaning in Dangme.

Keywords: participle, reduplication, allomorph, derivation, causative

\section{INTRODUCTION}

The participle is a word which is partly a verb and partly an adjective. They are often used as simple qualifying adjectives. These, precedes nouns in 
English. The participle has three forms; the present participle, the past participle and the perfect participle. The present participle is marked with the suffix \{-ing\} also referred to as the gerund form. This form formed from a transitive verb, takes an object. For example:

1a. upon seeing the man, the thief ran.

b. The child thinking it was safe dived into the river.

c. The wailing woman felt all was lost.

The past and perfect participles represent the completion of an action, a process, an event or state (research.omicsgroup.org/index.php./participle). Consider the following examples:

2a. Deceived by his colleagues, he went into hiding.

b. Driven by the headmaster, the pupil went home.

c. A dead goat is priceless.

It is argued in the literature that a participle used as an adjective has a passive meaning. This assertion is true to the current study of participle form of causative verbs in Dangme. Consider the following examples in English:

3a. A broken bottle can hurt someone becomes a bottle which is broken can hurt someone.

b. The boiled yam tastes nice becomes the yam that has been boiled tastes nice.

c. A gifted child moves mountains becomes a child who is gifted moves mountains.

d. An obedient child listens becomes a child who is obedient, listens.

This paper examines verbs with the participle-marking affix in expressing causation in Dangme. Causative verb is a verb that denotes causing something to happen. Such verbs are often formed from adjectives or nouns by means of causative suffixes: harden (to cause to become hard; to make hard), purify (to cause to become pure; to make pure), harmonize (to cause or create harmony; to make harmonious). Causation is thus a phenomenon that exists in almost all languages of the world. In many languages, causatives are useful theoretical constructs used to explain certain grammatical phenomena. The structure of causatives is seen in the first place by many researchers as morphosyntactic phenomena. Causatives are expressed by verbs and require the introduction of an argument(s). Causation is a situation in which something happens and it produces a result. It can be caused by a living entity or non-human entities. If it is non-human, it becomes an instrument (De Busser 2010).

A causative verb denotes an action, process or state that instigates a particular reaction or condition in another person or object. According to Dixon (2000:30), '... a causative construction involves the specification of an 
additional argument, a causer, onto a basic clause. A causer according to Dixon (2000), refers to someone or something which can be an event or state that initiates or controls the activity which is a defining property of the syntax-semantic function of a transitive subject.' De Busser (2010) argues that 'causatives are grammatical mechanisms that are used to express causation, i.e. they express that in addition to the main participants of the event, an additional participant, the causer, is relevant, which is not the main Agent of the event, but somehow causes it.' A causative construction illustrates who or what causes something to happen, (Dryer, 2005:49). Agyekum (2004), quoting (Lyons 1977), also states that causatives simply denote actions in which an entity causes something to happen either positively or negatively to another entity.

A causative situation involves two events: the causing event, which commonly corresponds to the way the event is initiated, and the caused event, which corresponds to either the resultant state or the performed action. Shibatani (1976:239) explains that a way to define the causative construction is, perhaps, by characterizing the 'causative situation'. He assumes that two events can be said to constitute a causative situation if the following two conditions exist:

a. The relation between the two events is such that the speaker believes that the occurrence of one event, the 'caused event', has been realized at a given or subsequent time (t2), which is after a given earlier first time (tl), the time of the 'causing event'.

b. The relation between the causing and the caused events is such that the speaker believes that the occurrence of the caused event is wholly dependent on the occurrence of the causing event. That is, the causing event most commonly depicts the way the event is initiated while the caused event designates either the result or the performed action. The mutual dependency of the two events must be to the extent that it allows the speaker to entertain a counter-factual inference that the caused event would not have taken place at that particular or subsequent time $\left(\mathrm{t}_{2}\right)$ if the causing event had not taken place at that earlier time $\left(t_{1}\right)$ provided that all things been equal. Thus, the beginning of the time of the process, state of affairs is time one $\left(t_{1}\right)$ and by the time the process or state of affairs ends, is at time two $\left(\mathrm{t}_{2}\right)$.

The participle is an affix which expresses completion having at the final stage of a process. All process verbs have a BECOME meaning element in them. As a verbal affix, the participle can take subjects and objects and have tense they also indicate active agency and an agency receiving an action (sufferer). According to Boadi, (2006:36) also (2010:41-50), participle is one of the morphological paradigms of the verb. It assigns a semantic role to the 
noun with which it occurs in the syntactic structure. It also has the cross linguistic semantic properties of verbs. He stated further that it codes one or more of universal states of affair: activity, state, process, and event. In Dangme, adjectives and nouns can be derived from the participle by derivational processes. Generally, affixes that express participial are in two forms: the finite and the non-finite categories. Unlike Akan and other languages that have both forms, Dangme has just the non-finite category.

Dangme is a three level tone language and it belongs to the Kwa group of Niger-Congo family of languages. It is spoken in two regions of GhanaEastern and Greater Accra mainly in South-Eastern Ghana. The people inhabit the coastal area of the Greater Accra Region, east of Accra, and part of the Eastern Region of Ghana. Its closest linguistic neighbours are Ga, Akan and Ewe. Dangme has seven dialects: Ada, Nugo, Kpone, Gbugblaa/Prampram, Osudoku, $\mathrm{S} \varepsilon$, and Krobo (Yilo and Manya). There are several small communities east of the Volta Region that trace their origins to Dangmeland; most of these have shifted to Ewe as the language of daily life, but others have not (Dakubu 1966; Sprigge 1969 cited in Ameka and Dakubu 2008:215). Patches of speakers are also found in Togo- Nyetoe and Gatsi.

Beyond the introduction, the paper is structured as follows: section one discusses the theoretical framework, the Role and Reference Grammar (RRG) used in this paper. Section two considers the lexical causative situation in which verbs express inherent causative meaning, the basis for the study on participle form of causative construction in Dangme. The formation of the participle is in the third section. Section four, examines the syntax and semantics of participle constructions in Dangme. It further looks at the modifying functions of the participle in Dangme and the fifth section, summarizes and comes out with the findings of the paper.

\section{THE THEORETICAL FRAMEWORK}

This paper employs the Role and Reference Grammar theory (henceforth, RRG.) in the description of the syntax and semantics of serial verb construction in Dangme. The Role and Reference Grammarians theory is proposed by Van Valin and Foley (1980), Jolly (1991) and their associates. RRG incorporates many of the points of views of current theories of functional grammar. RRG takes language to be a system of communicative social action, and accordingly, the communicative function of grammatical structures plays a vital role in grammatical description and theory from this perspective. It is in this sense that RRG is functional (Van Valin, 1993). The RRG posits a single syntactic representation for each sentence which corresponds to the actual form of the sentence. That is, grammatical units and construction are analysed primarily in terms of their functional roles in a linguistic system and secondarily in terms of their formal properties (Van Valin \& Foley, 1980). According to Van Valin (1993) the description of a 
sentence in RRG in a particular language is formulated in terms of (a) its logical (semantic) structure and communicative function, and (b) in terms of the grammatical devices that are available in the language for the expression of these meanings. Clause structure in RRG is captured in a semanticallybased model known as the "layered structure of the clause". The essential components of the layered structure of the clause are:

i. The CORE contains the nucleus plus the arguments of the predicate

ii. A PERIPHERY for each layer contains adjunct modifiers.

Labels used as mnemonics for the arguments positions include; (x) argument of all verbs that function as the Actor. The mnemonics for the second argument position is (y) in a two place predicate and (z) represents a three place argument structure as in ditransitive constructions. The Role and Reference Grammar assumes that there is a mapping relation between a semantic representation and a syntactic representation and the vice versa.

The aim of this paper is to describe the syntax and semantics of the participle form of causative verbs in Dangme which falls within the domain of lexical causatives.

\section{LEXICAL CAUSATIVE EXPLAINED}

Lexical causatives are single-clause expressions that encode the notions of cause and result. These two notions are encoded within a single verb such as melt, break, or kill hence the term 'lexical' (Song \& Wolff, 2003). Lexical causative verbs are a subset of transitive verbs in which the subject-causer engages in some action directed towards the patient-causee, and as a consequence of this action, the causee undergoes a change in state, or engages in another action. Semantically, the transitive lexical causative sentence describes the total control of the causer-subject over the cause-object and it is often construed as depicting manipulative causation (Shibatani, 1976: 259). Lexical causative verbs bear the causative meaning inherent in them. Consider (4a-b) below:

4a. Kate gbe to o.

Kate kill.AOR goat DEF

Kate killed the goat

'Kate caused the goat to die.'

dó [x Kate [CAUSE [BECOME not alive' ly to ऽ 'the goat']

4b. Ofori ywia atukpa a.

Ofori break.AOR bottle DEF

Ofori broke the bottle

'Ofori caused the bottle to be broken'. 


\section{dó [x Ofori [CAUSE [BECOME not whole'[y atukpa a 'the bottle']}

We observe in (4a) that the subject, Kate, did something which brought about the death of the goat, to כ. The action or inaction of the subject, Kate, has resulted in the goat, to $\supset$, changing its state from alive to not alive. Similarly, in (4b), Ofori the subject did something which is not indicated in the syntax that resulted in the object, atukpa a 'the bottle' transforming its state from being whole into pieces or fragments.

In Dangme, the participle has adjective-like characteristics as explained earlier and it is expressed mostly by the front vowels of Dangme: [i, e, $\varepsilon]$. The derived words refer to a process of change initiated by a causer (which is unspecified in the syntax). Let us consider the formation of the participle in the next section.

\section{THE FORMATON OF PARTICIPLES IN DANGME}

To form the participle in Dangme, two processes are required. Firstly, the verb stem is reduplicated either partially or totally depending on the shape of the verb stem. The reduplicant then selects a front vowel of the same tongue height level of the vowel of the verb stem. i.e. when a monosyllabic verb ends in the vowel $/ \mathrm{i} /, / \mathrm{e} /$ or $/ \varepsilon /$, the verb reduplicates in the process of participialization in Dangme, and the reduplicant is invariably suffixed to the verb stem. The verb stem denotes a change in state of an animate or inanimate thing. For example: $g b o$ 'to die' will be reduplicated as $g b o-g b o$ 'die-die'. It will then select and attach the front mid high vowel /e/ to the reduplicated verb; gbo-gbo-e 'dead'. The new word formed has shifted from the verbal category into the adjectival group as in English. When we examine the new word formation critically, we realize that the kind of reduplication that has taken place is the complete or total one since no part of the verb stem has been altered in the reduplicant part. We also notice that the vowel of the verb stem is the back mid high vowel $/ \mathrm{o} /$, and since the choice of the participial suffix depends on the front vowel counterpart of the verb stem vowel, /e/ has been suffixed to the reduplicated verb. The new word formed functions prototypically as adjectives in Dangme. I discuss the rules of reduplication in the next section.

\subsection{Rule of Reduplication}

Firstly, the verb root of the phonological shape, $\mathrm{CV}_{1}$ is reduplicated to $\mathrm{CV}_{1} \mathrm{CV}_{1}$ where $\mathrm{C}_{1} \mathrm{~V}_{1}$ has the same phonological feature as the reduplicated $\mathrm{C}_{1} \mathrm{~V}_{1}$. Consider example (5a-c):

5a. $\left[\mathrm{C}_{1} \mathrm{~L}_{4} \quad\left[\mathrm{C}_{1} \mathrm{~V}_{1}+\left[\mathrm{C}_{1}+\mathrm{V}_{1}\right]\right]\right.$

$$
\text { gbó gbó }+ \text { gbó }
$$




$$
\begin{array}{cc}
\text { die } & \text { die } \\
\text { 5b. } \underset{\left[\mathrm{C}_{1} \mathrm{~V}_{1}\right]}{\text { sì } \rightarrow} \underset{\text { fry }}{\longrightarrow} & \begin{array}{c}
{\left[\mathrm{C}_{1} \mathrm{~V}_{1}+\left[\mathrm{C}_{1}+\mathrm{V}_{1}\right]\right]} \\
\text { sì }+ \text { sì } \\
\text { fry }+ \text { fry }
\end{array}
\end{array}
$$

$$
\begin{aligned}
& \text { 5c. }\left[\mathrm{C}_{1} \mathrm{~V}_{1}\right] \longrightarrow\left[\mathrm{C}_{1} \mathrm{~V}_{1}+\left[\mathrm{C}_{1}+\mathrm{V}_{1}\right]\right] \\
& \text { sā } \\
& \text { bake/grill }
\end{aligned} \underset{\text { bake/grill }+ \text { bake/grill }}{\longrightarrow}
$$

\subsection{The Rule of Participle Formation}

The second process of the participle formation rests with the attachment of the participialised affix. The allomorphs of the participle affix are selected on two bases. Firstly, it is determined by the vowel height of the verb stem and by the rounded or unrounded nature of the vowel.

$$
\begin{aligned}
& \text { 6a. }\left[\mathrm{C}_{1} \mathrm{~V}_{1}\right] \longrightarrow[\mathrm{CVCV}]+\text { Participle } \\
& \text { gbó } \rightarrow \text { gbó-gbó }+ \text {-e } \\
& \text { die } \rightarrow \text { die-die + participle } \\
& \text { 'Dead' }
\end{aligned}
$$

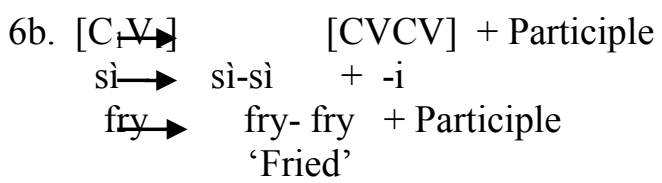

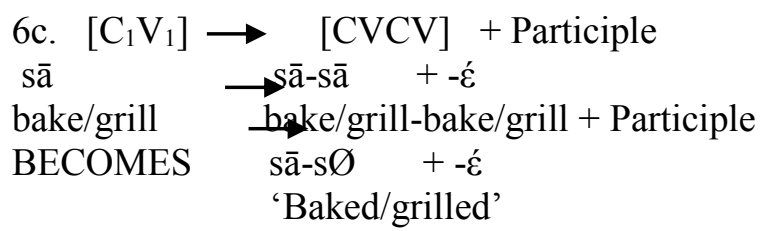

From example (6a), I have realized that when a monosyllabic verb ends in the vowel /o/, it reduplicates in Dangme, for example: gbó 'to die' becomes gbó-gbó 'die-die'. The reduplicated verb fronts the vowel of the verb stem. Thus, it selects and attaches the front mid high vowel /e/ to the reduplicated verb; gbo-gbo-e 'dead'. The new word formed has shifted from the verbal category into the modifier group as in English. In causation, gbó-gbó-é 'dead' accounts for the new state of a Causee after it has undergone a process of kill.

In (6b), this form of the verb adds a vowel whose quality is based on the quality of the vowel of the verb stem to the reduplicant. Thus, the high front vowel adds /i/ as its participial marking suffix as in si-si 'fry-fry' becoming si$s i-i$ ' fried'. The verb form changed class by the process of reduplication and 
suffixation that is, given a verb of the phonological structure CV, I apply the following rules: reduplication, suffixation, vowel fronting and vowel deletion if the vowel is low. However, there are other forms of monosyllabic verbs that end in /a/ which have the vowel of the verb roots raised and fronted to /- $\varepsilon /$ as their participle marking affix as indicated in the CV structure in (6c). For example: $s \tilde{a}$ 'grill/bake' reduplicates as $s \tilde{a}-s \tilde{a}-\varepsilon$ 'grill/bake-grill/bake'. In the process of deriving the participle, the low vowel of the reduplicant is deleted.

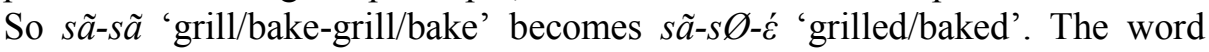
formed may be referred to as unaccusative verbs. These derived causative forms have their accompanying syntactic process which is discussed in the next section.

I consider $[\varepsilon]$ as the underlying vowel of the participial affix in Dangme simply because it ranks with two different classes of vowels, [a, o] of the verb root. Hence [i] and [e] are the allomorphs of the participle morpheme $[\varepsilon]$. When any of these allomorphs is attached to a reduplicated verb, it results in the internal change of state of a named object. This part of the process of participle formation has a morphophonemic implication which needs to be explained.

I will discuss each of the affixes in turns. I continue with the $\{-\mathrm{e}\}$ suffix.

\subsubsection{The $\{-\mathrm{e}\}$ Participle Suffix}

This section examines monosyllabic verb forms which change class by the process of reduplication and the suffixation of the participle suffix $\{-\mathrm{e}\}$. Let us consider the following examples in table (1):

Table 1

\begin{tabular}{|l|l|l|l|l|}
\hline $\begin{array}{l}\text { VERB } \\
\text { FORM }\end{array}$ & GLOSS & $\begin{array}{l}\text { REDUPLICATED } \\
\text { FORM }\end{array}$ & $\begin{array}{l}\text { PARTICIPLE } \\
\text { FORMED }\end{array}$ & GLOSS \\
\hline po & to cut & po-po & Po-po-e & cut part \\
\hline lo & to weave & lo-lo & lo-lo-e & woven \\
\hline to & iron/arrange & to-to & to-to-e & arranged \\
\hline ko & to pound & ko-ko & ko-ko-e & pounded \\
\hline gbo & to die & gbo-gbo & gbo-gbo-e & dead \\
\hline do & to sieve & do-do & do-do-e & sieved \\
\hline wo & to fruit & wo-wo & wo-wo-e & fruited \\
\hline tso & to burn & tso-tso & tso-tso-e & burnt \\
\hline tso & to crack & tso-tso & tso-tso-e & cracked \\
\hline
\end{tabular}

From the data in the table 1, we realize that when a monosyllabic verb that ends in the vowel /o/ reduplicates in Dangme, the reduplicant is invariably suffixed to the verb stem. To form the participle in this form, discussed in the introduction of this section, the reduplicative adds a vowel which quality is 
based on the quality of the vowel of the verb stem. In causation, the derived participle (adjective) denotes an entity which has been brought into a state after being subjected to a process of internal change depicted by the verb to which the affix is attached (Boadi, 2010:48). For instance,
$7 \quad$ Sa lo-lo-e
0 ng $\varepsilon$
feu.
Mat weave-RED-Participle DEF is
beautiful
Mat CAUSE to be weave.PERF-Participle
'The woven mat is nice.'

In (7), the derived adjective, loloe 'woven' expresses a process of weaving that is complete.

\subsubsection{The $\{-i\}$ Participle Suffix}

I now move to the second participle affix $\{-\mathrm{i}\}$ in the following table 2 :

Table2

\begin{tabular}{|l|l|l|l|l|}
\hline $\begin{array}{l}\text { VERB } \\
\text { STEM }\end{array}$ & GLOSS & $\begin{array}{l}\text { REDUPLICATED } \\
\text { FORM }\end{array}$ & $\begin{array}{l}\text { PARTICIPLE } \\
\text { FORM }\end{array}$ & GLOSS \\
\hline fu & to ripe & fu-fu & fu-fu-i & riped \\
\hline $\mathrm{pu}$ & to burry & pu-pu & pu-pu-i & buried \\
\hline $\mathrm{ju}$ & to steal & ju-ju & ju-ju-i & stolen \\
\hline $\mathrm{bu}$ & to sow & du-du & du-du-i & $\begin{array}{l}\text { that can be } \\
\text { sown }\end{array}$ \\
\hline nu & to drink & nu-nu & nu-nu-i & $\begin{array}{l}\text { drinkable/that } \\
\text { can be drunk }\end{array}$ \\
\hline su & to light & su-su & su-su-i & $\begin{array}{l}\text { that can be } \\
\text { lightened }\end{array}$ \\
\hline si & to fry & si-si & si-si-i & fried ... \\
\hline fi & to tie & fi-fi & fi-fi-i & tied ... \\
\hline mi & $\begin{array}{l}\text { to } \\
\text { swallow }\end{array}$ & mi-mi & mi-mi-i & $\begin{array}{l}\text { that can be } \\
\text { swallowed }\end{array}$ \\
\hline ni & to twist & ni-ni & ni-ni-i & twisted... \\
\hline
\end{tabular}

The data in table (2), depicts that when a monosyllabic verb that ends in the vowel / $u$ or $i /$ reduplicates in the process of participialization in Dangme, the reduplicant is invariably suffixed to the verb stem. This form of verbs adds a vowel which quality is based on the quality of the vowel of the verb stem to the reduplicant. Thus, the high back or front vowel selects the high front vowel. The low tone of the verb root is repeated in the reduplicant. The participialised affix however bears the high tone as illustrated in the table 2 above. 


\section{To ju-ju-i o kle. \\ goat steal-RED-Participle DEF big goat CAUSE.AOR BECOME steal.PERF-Participle is big 'The stolen goat is big.'}

In (8) the participial affix $\{-i\}$ is suffixed to a verb stem in each of the sentence. The participle jujui 'stolen' designates a change of location which was achieved through by unlawfully acquiring that property. The process of achieving the set purpose is said to be complete.

\subsubsection{The $\{-\varepsilon\}$ Participle Suffix}

We now examine the last affix of the participle in Dangme. Consider the following examples in tables 3 and 4 :

Table 3

\begin{tabular}{|c|c|c|c|c|}
\hline $\begin{array}{l}\text { VERB } \\
\text { FORM }\end{array}$ & GLOSS & $\begin{array}{l}\text { REDUPLICATED } \\
\text { FROM }\end{array}$ & $\begin{array}{l}\text { PARTICIPLE } \\
\text { FORM }\end{array}$ & GLOSS \\
\hline 15 & to lick & 10-10 & $10-1 b-\varepsilon$ & $\begin{array}{l}\text { That can be } \\
\text { licked }\end{array}$ \\
\hline gbo & $\begin{array}{ll}\text { about } & \text { to } \\
\text { ripe } & \end{array}$ & gbo-gbo & gbo-gbo- $\varepsilon$ & ripped \\
\hline po & to wet & po-po & po-po- $\varepsilon$ & wet \\
\hline kplo & $\begin{array}{l}\text { ripple/plug/ } \\
\text { prun }\end{array}$ & kplo-kpl॰ & kplo-kplo- $\varepsilon$ & $\begin{array}{l}\text { crippled/plugged/ } \\
\text { pruned }\end{array}$ \\
\hline bo & to burn & bo- bo & bo-bo- $\varepsilon$ & burnt \\
\hline ho & to insert & ho- ho & 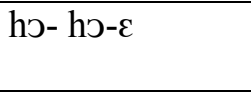 & $\begin{array}{l}\text { that can be } \\
\text { inserted }\end{array}$ \\
\hline jo & be pure & jo- jo & $j \supset-j \partial-\varepsilon$ & pure \\
\hline $\mathrm{kpo}$ & to reject & kpэ- kpэ & 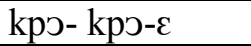 & rejected \\
\hline ngo & be sweet & ngo- ngo & ngว- ngว- $\varepsilon$ & that tastes nicely \\
\hline
\end{tabular}

Table 4

\begin{tabular}{|c|c|c|c|c|}
\hline $\begin{array}{l}\text { VERB } \\
\text { FORM }\end{array}$ & GLOSS & $\begin{array}{l}\text { REDUPLIC } \\
\text { ATED } \\
\text { FROM }\end{array}$ & $\begin{array}{l}\text { PARTICIPL } \\
\text { E FORM }\end{array}$ & GLOSS \\
\hline $\mathrm{ka}$ & tall/long & ka-ka & ka-kØ- $\varepsilon$ & height \\
\hline pa & $\begin{array}{l}\text { to } \\
\text { drink/borr } \\
\text { ow }\end{array}$ & pa-pa & 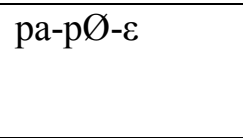 & $\begin{array}{l}\text { drinkable/borro } \\
\text { wed }\end{array}$ \\
\hline sã & $\begin{array}{l}\text { to } \\
\text { grill/bake }\end{array}$ & sã-sã & 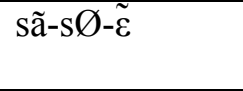 & grilled/baked \\
\hline sa & to rot & sa-sa & sa-sØ-ع & rotten \\
\hline
\end{tabular}




\begin{tabular}{|l|l|l|l|l|}
\hline da & $\begin{array}{l}\text { to } \\
\text { straighten }\end{array}$ & da-da & da-dØ- $\varepsilon$ & straightened \\
\hline ta & to chew & ta-ta & ta-tØ- $\varepsilon$ & chewable \\
\hline wa & to grow & wa-wa & wa-wØ- $\varepsilon$ & matured \\
\hline gba & to tear & gba-gba & gba-gbØ- $\varepsilon$ & torn \\
\hline ngla & to burn & ngla-ngla & ngla-nglØ- $\varepsilon$ & burnt \\
\hline ngma & to write & ngma-ngma & $\begin{array}{l}\text { ngma-ngm } \varnothing- \\
\varepsilon\end{array}$ & written \\
\hline
\end{tabular}

Table 3, contains verb stems that ends in the vowel / $/$. Participles are derived from these verb forms by first through a complete or total reduplication as in the case of the participial affxes $\{-\mathrm{e}\}$ and $\{-\mathrm{i}\}$. The reduplicant is invariably suffixed to the verb stem. The process is then completed with the suffixation of the participial affix $\{-\varepsilon\}$ which is of the same quality as the vowel of the verb stem to the reduplicated verb. Thus, the mid low back vowel selects the mid low front vowel as its participial marking suffix. In table 4, however, the type of reduplication that takes place in the verb form is the partial one. In the process of deriving the participle, the low vowel of the reduplicant is deleted before the participle suffix $\{-\varepsilon\}$ is attached to the verb. See example $(9 a-b)$,

$\begin{array}{llclll}\text { 9a. } & \text { Mangoo } & \text { gbo-gbo- } \varepsilon & \text { ko nge } & \text { kusii mi. } \\ \text { Mango } & \text { rip-RED-Participle } & \text { INDEF in } & \text { basket }\end{array}$
inside

mango CAUSE.AOR BECOME ripped is in a basket. 'The ripped mango is in a basket.'

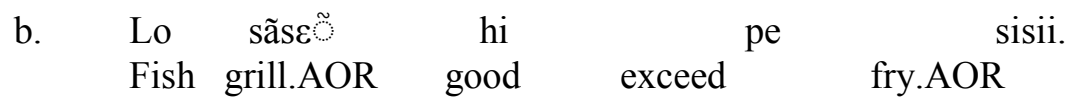

Fish CAUSE.AOR to grill is better than a fried one

'Grilled fish is better than a fried one.'

In (9a) we have the verb gbo 'rip' from which the participle gbogbo $\varepsilon$ 'ripped' is derived. This process is achieved through a total reduplication of the stem verb and the suffixation of the participle affix $\{-\varepsilon)$ to the verb form. The makeup of the mango has undergone some change. The process which is said to be complete brought about the new condition in the mango gbogbo $\varepsilon$ ripped. In (9b), the participles, sãse 'grilled' has been derived by partial reduplication from the verb stems: $s \tilde{a}$ 'to grill'. 


\subsection{The syntax and semantics of the participialised verbs (Causative Derivation)}

Causative derivation takes the form of an intransitive clause. The derived participle, forms a different word class. Their meaning has a time span covering the time of the initiation of the process $\left(t_{1}\right)$ and endpoint at $\left(t_{2}\right)$. Participle form of causative verbs are among the verbs containing an inherent semantic component of "cause of become or change of state'. In sentences of this kind, the Causer is not included in the intransitive clause (Dixon \& Aikhenvald, 2000:13; 1997:82). Consider for example (10):

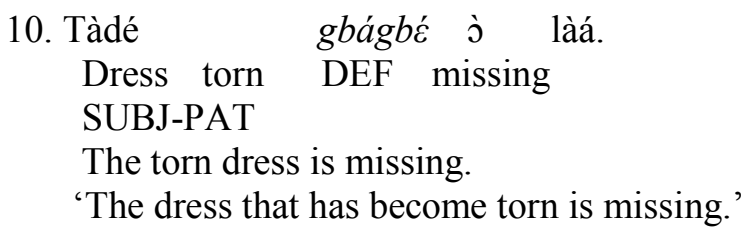

The participle adds another meaning to the cause verbs. The derived causatives are only employed for semantic reasons. In such cases, the original intransitive Subject becomes the Causee of the causative construction. Thus, the Object then assumes the subject position to satisfy the Extended Projection Principle rule (EPP). In (10), for instance, tàdé gbágbé jòàa. 'the torn dress is missing', tàdé 'a dress' is the Subject of the intransitive clause and the Causee whose 'state of being' has been changed by an unexpressed Causer. The Subject of the new state designated by the verb gbágbé 'torn' is said to be Patient. The causavization of verbs of this nature gives the meaning of a resultative state (Rice, 2000:202).

This kind of causative formation does not follow the prototype form of transitive as demonstrated in (10); they mostly have the intransitive forms without overt Causers which can be interpreted to mean that a non-animate Causee is acted upon by an unexpressed Causer to bring about a change of state in the Causee as in (10). The result of this is that, the Patient of Cause undergoes a process at the end of which its original state is completely different from its final state. Hence, the Complement-Patient becomes Subject-Patient. In a periphrastic causative construction, the Complement of a participialised verb can function as an Object-Causee as in (10b):

$\begin{array}{llrl}\text { 10b. Àlímò há } & \text { Dede } & k p \varepsilon & \text { tàdé gbágbé j. } \\ \text { Allímò make } & \text { Dede } & \text { sew } & \text { dress torn DEF } \\ \text { SUBJ of Cause } & \text { SUBJ of Cause } & \text { OBJ-CAUSEE } \\ \text { 'Àlímò made Dede sew the torn dress.' } & \end{array}$


Consider the following sentences in which some of these participle forms are used to express causation. I examined the underlying transitive causative sentences and then the derived intransitive constructions of these verbs in this section.

11a. Akuorkor pò bò j̀.
Akuorkor cloth DEF
AGENT of Cause
Akuorkor CAUSE BECOME wet Cloth the
'Akuorkor caused the cloth to become wet.'

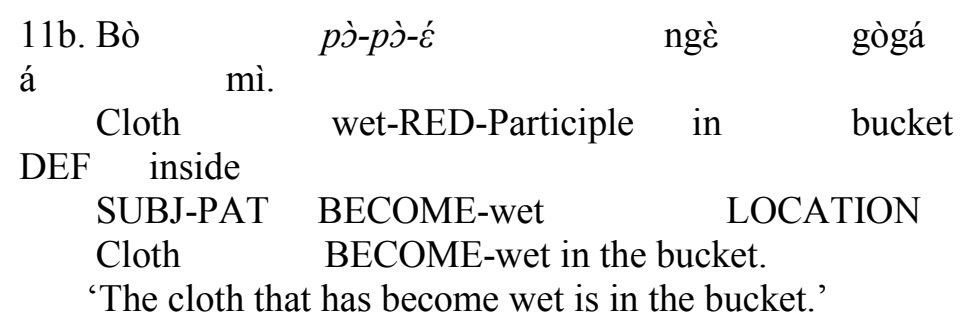

(11a) contains a transitive verb. It is causative. It has Akuorkor as the Subject and Agent of Cause and $b \dot{c} j$ 'the cloth' as the Patient of Cause of the verb $p j$ ' 'wet'. The sentence means that Akuorkor changed the state of the cloth from being dry to being wet. This new state of the cloth $b \dot{o} j$ came as a result of the Agent-Causer submerging it in liquid (not specified in the syntax). The verb $p j$ expresses both the action and the result of the action initiated by the Subject, Akuorkor. The cloth at this point would not have been wet at time two $\left(\mathrm{t}_{2}\right)$ if Akuorkor had not at an earlier time ( $\left.\mathrm{t}_{1}\right)$ applied some liquid to it.

Sentence (11b) is formed from the verb root $p j$ 'wet' as mentioned earlier. This sentence is intransitive because it has only one argument, $b \dot{o} j$ 'the cloth'. Bo $j$ becomes a Subject Undergoer of $p j$ 'wet'. The make-up of the cloth has undergone some change by dipping it into some form of liquid not stated in the syntax. The process which is said to be complete brought about the new condition in the cloth $p$ эр $\varepsilon$ ' wet'. These events in the Causee may be triggered off by the action of the Causer which in this case is unexpressed. But something brought it about that $b \dot{o} j$ 'the cloth' is wet. The situation represented in sentence (11b) is to be interpreted to mean that a nonanimate Patient bo ' $j$ 'the cloth' is acted upon by an unexpressed Actor. The result of this is that, the Subject-Causee $b \dot{o} j$ undergoes a process of being in liquid at a location indicated in the Periphery ngè gògá á mì 'in a bucket' at the end of which its original state is completely different from its final state. It has BECOME wet. 
The transitive and the derived intransitive causative sentences in (11a-b) can be illustrated on tree diagrams. Tree diagram (vii) mapped the underlying semantic structure of sentence (11a) on to the syntax:

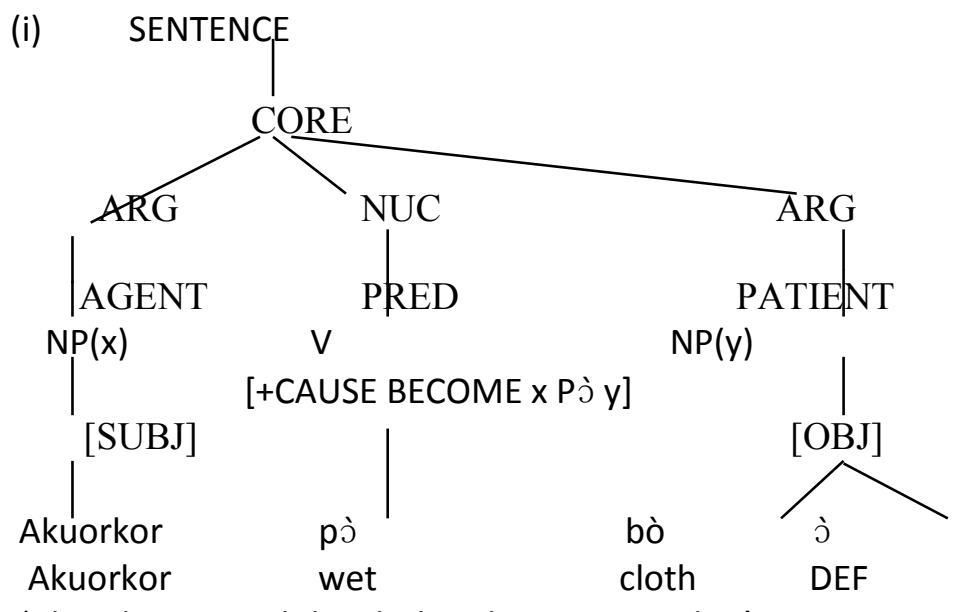

'Akuorkor caused the cloth to become not dry.'

The semantic representation is as below:

dó[(x, Akuorkor [CAUSE [BECOME $\boldsymbol{p} \dot{j}$ (not dry) [y, bò $j$ 'the cloth')]]]]

In diagram (i) above, there are two Core Arguments. These are Akuoko the Agent of Cause and bo $j$ 'the cloth' the Patient of Cause. Akuorkor is responsible for the new state of the Undergoer, $b \dot{o} j$ denoted by the verb of Cause $p j$ ' wet'. This new state of the Object-Patient at time two $\left(\mathrm{t}_{2}\right)$ would not have been possible if the Agent of Cause, Akuorkor at an earlier time ( $\left.\mathrm{t}_{1}\right)$ had not used an Instrument which is not expressed in the syntax to do so. 
The participle form of causative construction of $(11 \mathrm{~b})$ is derived as below:

(ii)

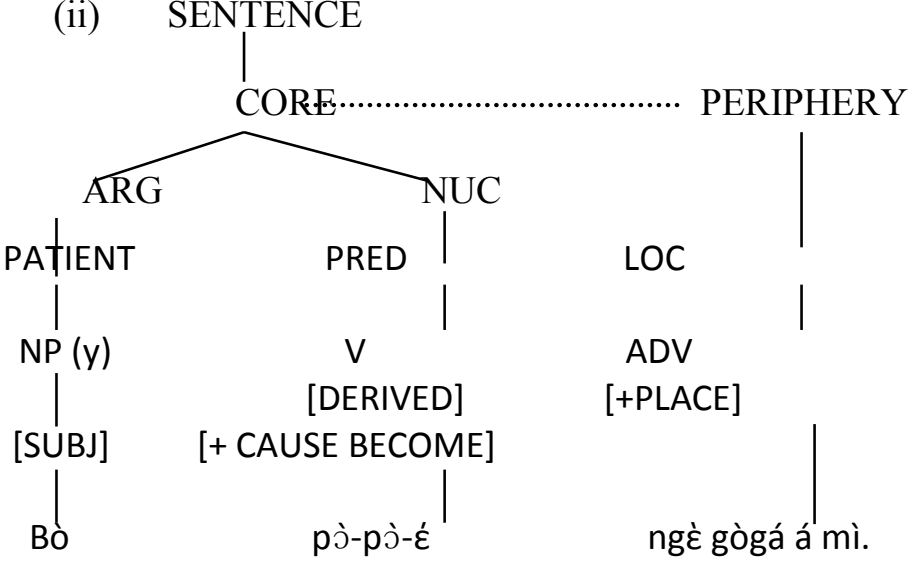

Cloth wet-RED-Participle Affix in bucket.DEF inside

'The cloth that has become wet-wet is in the bucket.'

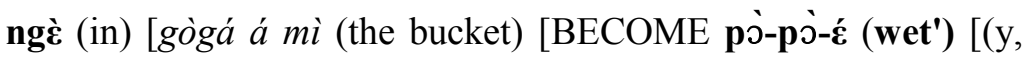

bò $う$ (the cloth)]]]

Diagram (ii) shows that there is an unexpressed Causer for the new state of the Patient of Cause, $b \dot{o}$ 'cloth'. So the Subject position is empty. Bo then functions as the Subject of $p \grave{j}-p \grave{j}-\varepsilon$ ' 'wet'. At the same time, $p \dot{j}-p \dot{j} \bar{\varepsilon}$ assigns the role of Patient of Cause to $b \dot{o}$ 'cloth'. Bò then fills in the first argument position of tree diagram (viii) with all its assigned semantic properties as it is in (11a).

The separate syntactic structure representation for sentences (11a) and (11b) are related semantically because the absence of the Causer in (11a) did not present a diverse view of meaning in the sentence in (11b) above. Both sentences have element of causation. (11a) implies that $x$ CAUSE $y$ BECOME wet and (11b) illustrates that something happened and $\mathrm{y}$ is in a state of $p \grave{j}-p \dot{j}-\dot{\varepsilon}$ (wet).

Consider the following sentences in which some of these participles are used.

12

$$
\text { Atsoko po-o lo o. }
$$

Atsoko CAUSE to cut.AOR fish/meat DEF

Atsoko caused the fish/meat to cut into pieces

'Atsoko cut the fish/meat into pieces.'

12b. Lo

$$
\text { po-po-e }
$$

0

ngoo.

Fish/meat

cut-RED-Participle

DEF tasty

Fish/meat CAUSE.AOR BECOME cut into pieces-Participle tasty 
'The piece of fish/meat is tasty.'

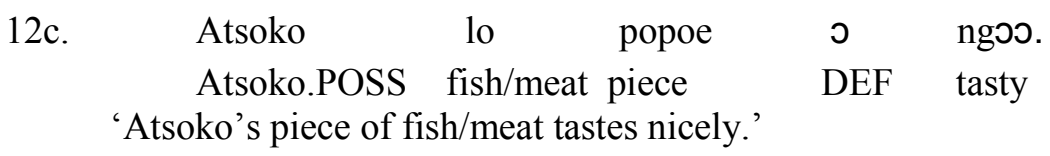

In sentences 12(a), the participial affix $\{-\mathrm{e}\}$ attached to a verb in each of the sentence, functions as a participle. And in (12c), popoe (piece of) denotes that the process of cutting is over and the outcome of the action is the piece of fish/meat that is said to be tasty. These process verbs are causative and they require that their underlying complement participants undergo a process of internal change initiated by a covert agent or instrument of cause (Boadi, 2010:50) He explains that the complement is referred to us Patient of Cause. Sentence (8) is an example of such a sentence.

Below is a tree diagram representation the underlying structure of sentence (8):

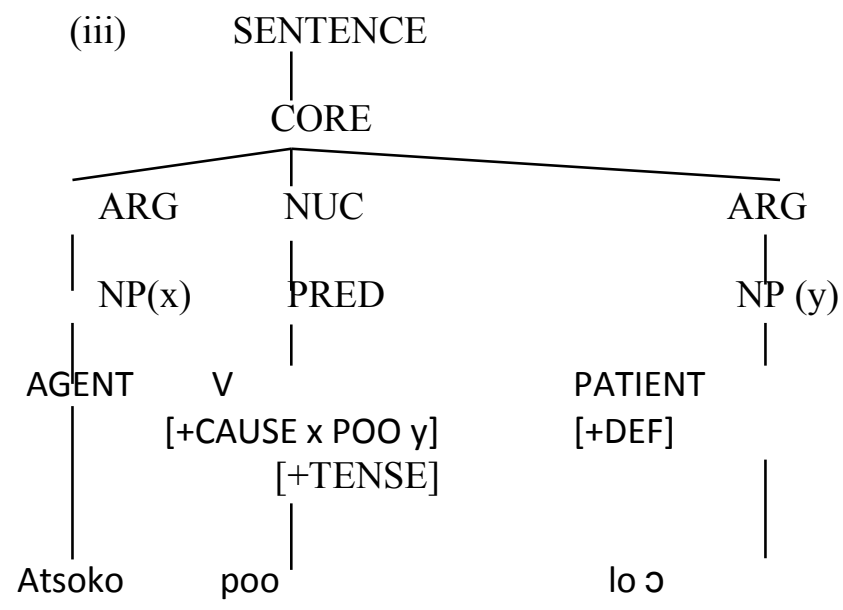

Atsoko CAUSE BECOME pieces fish/meat DET 'Atsoko caused the fish/meat become pieces.'

Example (12a), has two arguments: Atsoko, the Agent of cause and lo 0 'the fish/meat' is the Patient of cause. Atsoko is said to be responsible for the new state of the undergoer, lo 0 denoted by the verb of cause poo 'cut into pieces'. This new state of the Patient at time two $\left(t_{2}\right)$ would not have been possible if the causer, Atsoko at an earlier time $\left(\mathrm{t}_{1}\right)$ had not used an instrument which is not expressed in the syntax to do so. The participle structure is derived as below: 
(12b) is represented on a tree diagram as below:

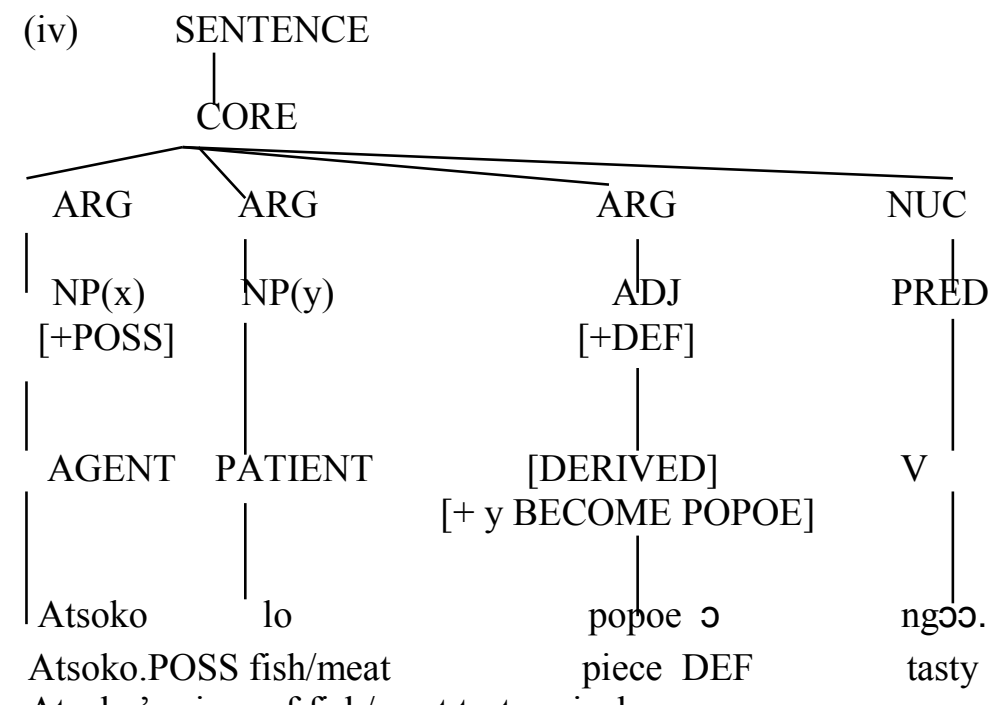

I now look at similar construction in (13a-16b) with different verbs of BECOME.
13 a. Làákò
nglá
àgbèlì j̀.
Làákò
burn.PERF
cassava DEF
AGENT of Cause
PATIENT of

Cause

Làákò Cause-BECOME-burnt the cassava

'Làákò caused the cassava to become burnt.'

13b. Àgbèlì

Cassava

available

SUBJ-PAT

Cassava BECOME-burnt is the only one available

'It is only a cassava that has become burnt which is available.'

14a. Mámà

Mámà.POSS hand

SUBJ-INSTRUMENT of Cause

Cause

Mámà's

hand Cause-BECOME-rotten the dough

'Mámà's hand caused the dough to become rotten.' pé lè ngغ̀.

only FOC 
14b. Má

Dough

SUBJ-PAT

Dough sāsé

rot.PERF

BECOME-rotten

BECOME-rotten not good. hí.

good.NEG

'Rotten dough is not good.'

$\begin{array}{ccrcr}\text { 15a. Kòjó } & \text { gbè } & \text { tò kò } & \text { kغ่ } & \text { fò } \\ \text { Kòjó } & \text { kill goat INDEF } & \text { take put } \\ \text { AGENT } & \text { CAUSE PATIENT of Cause } & \end{array}$

tsù $\quad$ j̀ sè.
house.OBLQ DEF back
LOCATION

'Kòjó caused the goat to die at the back of the house/the goat is dead.'

15b. Tò

gbó-gbó-é

kò ngè tsù

$\grave{\jmath}$

sè.

Goat die-RED-Participle INDEF in room.OBLQ DEF back

SUBJ-PAT BECOME-dead LOCATION

'A goat that has become dead is at the back of the house.'

16a. Àgbèdùgbè

sì hyغ̀

mùonc่ j̀.

Àgbèdùgbè

fry.PERF yam.

today DEF

AGENT of Cause

PATIENT of Cause

TIME

Àgbèdùgbè CAUSE BECOME FRIED the yam

The yam has been caused by Àgbèdùgbè to become fried

'Agbedugbe caused the yam to be fried.'

16b. Hyغ่

$$
\text { sì-si-í }
$$

ngว̀े.

Yam

fry-RED-Participle

ADJ

SUBJ-PAT

BECOME fried

sweet

Yam BECOME fried is sweet.

Fried yam is sweet.

'The yam that has become fried is sweet.'

In (13b) and (14b), the participles, sāsé 'rotten' and nglánglé 'burnt' have been derived by reduplication, suffixation and reduplicant vowel deletion from the verb roots: $s \bar{a}$ 'rot' and nglá 'burn' in (13a) and (14a). (13a) has Làákò as the Subject-Agent of Cause, and nglá 'burn' as the Predicate of 
Cause. In (14a) Mámà's hand is an Instrument of Cause that has assumed the Subject position of the clause. Mámà nine functions as an Instrument-Causer that did something which brought about the change of state in the ObjectCausee má. As in (12b), Aggèlì is the Subject-Patient of Cause and the Complement of nglánglé (burnt) in (13b) and má in (14b). (13b) and (14b) imply that àgbèlì the Patient of Cause has experienced some form of internal change depicted by the verb nglá 'burn'. And má 'dough' has been caused to change state from being fresh to being rotten. Verbs of these forms are causative and they require that their underlying Complement participants undergo a process of internal change initiated by a covert Agent or Instrument of Cause (Boadi, 2010:50). Consider other examples in (15a-15b).

Sentence (15a) has an overt Agent of Cause, Kojó, and a Patient of Cause tò (goat) as in (12a) and (13a) above. The verb of Cause, gbè 'kill' has been discussed in the previous section in (2a) so I described its derived participle only in (15b). In sentence (15b), to 'goat' is the Undergoer of the process of gbó 'die'depicted by the verb. Ngè tsù j̀ sè 'at the back of the house' indicates the location of the dead goat. Tò is then the Patient of Cause and the Complement of gbó 'die'. The word gbó-gbó-é 'dead' marks a change of state which was achieved through the process of dying which is complete.

There are two arguments in (16a): Agbedugbe, the Subject and Agent of Cause and hys 'yam' the Object-Undergoer. Si 'fry' is the verb of Cause in the Predicate. The Subject-Agent of Cause is construed as been responsible for the new state of the hys̀ 'yam'. The result of this sentence is that Agbedugbe changed the state of the yam from being fresh to being fried. This new state of the yam came as a result of the Causer cooking the hys 'yam' in oil. (16b) just like (12b), (13b), (14b) and (15b) is an intransitive form of causative construction. This implies that it has one argument which is the SubjectPatient and Complement of si-si-i 'fried'. These processes of wetting, burning, rotting, dying and frying encoded by the VP's in (12-16) have changed the state of the Causees bò, àgbèlì, má, tò and hyè from their original states of 'not wet', 'not burnt', 'not rotten', 'not dead' and 'not fried' to become 'wet', 'burnt', 'rotten', 'dead' and 'fried'. These changes are internal. All these participles can function as one of the modifiers of nouns in Dangme. All these participles can function as one of the modifiers of nouns in Dangme.

\subsection{The Modifying Function of the Participle in Dangme}

The verb-participle functions as one of the modifiers of nouns in Dangme. According to Boadi (2010:41), 'a noun modified by a verb participle denotes an entity which has been brought into a state after being subjected to a process of internal change depicted by the verb to which the affix is attached. $\mathrm{He}$ further explained that a complete process marks the state as a result.'

Consider the following examples: 
$\begin{array}{llll}\text { 17. Saki ju lo } \quad \text { sàsé } & 0 & \text { hic. } \\ \text { Saki steal.AOR fish/meat gill.RED.Participle } & \text { DEF } & \text { yesterday } \\ \text { 'Saki stole grilled fish/meat yesterday.' } & & \end{array}$

18. Margaret he madaa sisii piani

nย ว.

Margaret buy.AOR plantain fry.RED.Participle afternoon this

'Margaret bought fried plantain this afternoon.'

Sentence (17) implies that Saki is the subject of cause expressed by the verb $j u$ 'steal' and $l o$ 'fish/meat' is the object of cause or the undergoer of the action designated by the agent causer. Saki is construed as unlawfully acquiring the said fish or meat that has been caused to be cooked by bringing it into direct contact with fire. That is the fish/meat' lo has undergone a complete process of grilling and has become sàsé ' grilled'. In (18), Margaret functions as the subject agent of cause and madaa 'plantain' as the object of cause expressed by he 'buy'. Margaret is said to have acquired a kind of plantain that has undergone a complete change by causing it to be cooked in hot oil. So madaa sisii 'fried plantain' is in a state of friedness.

These processes of stealing and buying encoded by the VP's in (17-18), indicate the change of location of the causees. And the processes of grilling and frying have changed the state of the causes lo and madaa from their original states of not grilled and not fried to grilled and fried. These changes are internal. In the structure of a clause, the participle comes after the noun it modifiers. See (17-18).

The table (5) below gives the underlying forms of noun and verbs from which the verb participle is derived in Dangme. The second column presents data on verb participle modifying NPs.

Table 5.

\begin{tabular}{|c|c|}
\hline $\begin{array}{c}\text { Underlying Forms of NP VP } \\
\text { and VP NP }\end{array}$ & $\begin{array}{c}\text { Derived Verb Participles } \\
\text { Modifying NPs }\end{array}$ \\
\hline $\begin{array}{c}\text { kplo mangoo } \\
\text { 'plug mangoo' }\end{array}$ & $\begin{array}{c}\text { mangoo kplokploś } \\
\text { 'a mango that has been plugged' }\end{array}$ \\
\hline $\begin{array}{c}\text { to wa } \\
\text { 'goat mature' }\end{array}$ & $\begin{array}{l}\text { to wawś } \\
\text { 'a goat that has become matured.' }\end{array}$ \\
\hline $\begin{array}{c}\text { ngla agbeli } \\
\text { 'burn cassave' }\end{array}$ & $\begin{array}{l}\text { agbeli nglanglé } \\
\text { 'cassava that is burnt' }\end{array}$ \\
\hline $\begin{array}{c}\text { bla bo } \\
\text { 'join cloth' }\end{array}$ & $\begin{array}{l}\text { bo blablé } \\
\text { 'a cloth that has been joined' }\end{array}$ \\
\hline $\begin{array}{c}\text { sa lo } \\
\text { 'grill fish/meat' }\end{array}$ & $\begin{array}{l}\text { lo saś́ } \\
\text { 'fish/meat that has been grilled; }\end{array}$ \\
\hline
\end{tabular}




\begin{tabular}{|c|c|}
\hline $\begin{array}{lr}\mathrm{da} & \text { dade } \\
\text { 'straigthen iron' }\end{array}$ & $\begin{array}{l}\text { dade dadé } \\
\text { 'an iron that has been } \\
\text { straightened' }\end{array}$ \\
\hline $\begin{array}{ll}\text { ta } & \text { kotsa } \\
\text { 'chew } & \text { sponge' }\end{array}$ & $\begin{array}{l}\text { kotsa taté } \\
\text { 'sponge that is chewable' }\end{array}$ \\
\hline $\begin{array}{l}\text { kpe tade } \\
\text { 'sew dress' }\end{array}$ & $\begin{array}{l}\text { tade kpekpé } \\
\text { 'a dress that has been sewn' }\end{array}$ \\
\hline $\begin{array}{l}\text { lo bagi } \\
\text { 'weave bag' }\end{array}$ & $\begin{array}{l}\text { bagi loloe } \\
\text { 'a bag that has been woven' }\end{array}$ \\
\hline 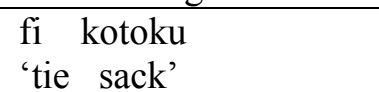 & $\begin{array}{l}\text { kotoku fifii } \\
\text { 'a sack that has been tied' }\end{array}$ \\
\hline $\begin{array}{l}\text { gbe to } \\
\text { 'kill goat' }\end{array}$ & $\begin{array}{l}\text { to gbogboe } \\
\text { 'a goat that is dead' }\end{array}$ \\
\hline $\begin{array}{l}\text { po nane } \\
\text { 'cut leg' }\end{array}$ & $\begin{array}{l}\text { nane popoe } \\
\text { 'a leg that is cut' }\end{array}$ \\
\hline $\begin{array}{l}\text { po blefo } \\
\text { 'soak maize' }\end{array}$ & $\begin{array}{l}\text { Blefo popoś } \\
\text { 'maize that has been soaked' }\end{array}$ \\
\hline $\begin{array}{l}\text { si akate/gigé } \\
\text { 'roast groundnut' }\end{array}$ & $\begin{array}{l}\text { akate/gigé sisii } \\
\text { 'groundnut that has been roasted' }\end{array}$ \\
\hline $\begin{array}{l}\text { kpe afungu } \\
\text { 'chew sugarcane' }\end{array}$ & $\begin{array}{l}\text { afungu kpekpe } \\
\text { 'sugarcane that is chewable' }\end{array}$ \\
\hline $\begin{array}{l}\text { du wu } \supset \\
\text { 'sow the seed' }\end{array}$ & $\begin{array}{l}\text { wu dudui } \\
\text { 'seed that can be sown' }\end{array}$ \\
\hline $\begin{array}{l}\text { fo bi } \\
\text { 'give birth to a child' }\end{array}$ & $\begin{array}{l}\text { bi fofor } \\
\text { 'a child that can be bore' }\end{array}$ \\
\hline $\begin{array}{l}\text { tso ywie ngme } \\
\text { 'crack the palm kernel' }\end{array}$ & $\begin{array}{l}\text { ywie ngme tsotsoe } \\
\text { palm kernel that is cracked or can } \\
\text { be cracked }\end{array}$ \\
\hline $\begin{array}{l}\text { pu dwomi } \supset \\
\text { 'burry the rubbish' }\end{array}$ & $\begin{array}{l}\text { dwomi pupui } \supset \\
\text { 'the buried rubbish' }\end{array}$ \\
\hline $\begin{array}{l}\text { gba zugba a } \\
\text { 'share the land' }\end{array}$ & $\begin{array}{l}\text { zugba gbagbe } ~ \\
\text { 'the shared land or the land that } \\
\text { can be shared }\end{array}$ \\
\hline
\end{tabular}

\section{SUMMARY}

This paper reveals that participles in Dangme can be formed through total and partial reduplication of the verb stem and an addition of a vowel. The choice of the participial vowel depends largely on the quality of the verb stem vowel. That is, if the verb stems vowel ends in $[\mathrm{u}$, or $\mathrm{i}, \mathrm{o}, \mathrm{J}]$ then $[\mathrm{i}, \mathrm{e}, \varepsilon]$ is suffixed respectively to the reduplicant part of the verb to derive a participle, for example: gbo 'to die' becomes gbogboe 'dead'. However, monosyllabic verbs that end in the low back vowel /a/, do not attach any vowel to their reduplicant rather, the vowel of the reduplicant is deleted in the process and 
the front mid low vowel is suffixed to the verb for instance, $s a$ 'to rot' becomes sase 'rotten'. The new words formed are process verbs which have been caused to change their forms. According to Boadi (2010), these process verbs are causative and they require that their underlying complement participants undergo a process of internal change initiated by a covert agent or instrument of cause.

In dealing with the syntax and semantics of participles also referred to as causative derivation Rice (2000), it was realized that such a derivation participle, takes the form of an intransitive clause. The derived participle forms a different word class. Their meaning has a time span covering the time of the initiation of the process $\left(t_{1}\right)$ and endpoint at $\left(t_{2}\right)$. The data shown also that the participle form of causative verbs are among the verbs containing an inherent semantic component of "cause of become or change of state'. The derived words function prototypically as adjectives in Dangme to modify the NP as exemplified in table 5.

\section{ABBREVIATIONS}

$\begin{array}{ll}\text { ADJ } & \text { Adjective } \\ \text { ADV } & \text { Adverb } \\ \text { ARG } & \text { Argument } \\ \text { AOR } & \text { Aorist } \\ \text { CAUS } & \text { Cause } \\ \text { CAUSE } & \text { Causative } \\ \text { CV } & \text { Consonant and a Vowel } \\ \text { DEF } & \text { Definite Article } \\ \text { INDEF } & \text { Indefinite Marker } \\ \text { LOC } & \text { Locative } \\ \text { NP } & \text { Noun Phrase } \\ \text { NEG } & \text { Negation } \\ \text { NUC } & \text { Nucleus } \\ \text { OBJ } & \text { Object } \\ \text { OBLQ } & \text { Oblique } \\ \text { PAT/PATIENT } & \text { Patient } \\ \text { PART } & \text { Participle } \\ \text { PERF } & \text { Perfective } \\ \text { POSS } & \text { Possessive } \\ \text { PRED } & \text { Predicate } \\ \text { PERF } & \text { Perfect } \\ \text { RRG } & \text { Role and Reference Grammar } \\ \text { SUBJ } & \text { Subject }\end{array}$




$\begin{array}{ll}\text { SUB-PAT } & \text { Subject Patient } \\ t_{1} & \text { The Time of the Event } \\ t_{2} & \text { After a Given Earlier Time } \\ V & \text { Verb } \\ \text { VP } & \text { Verb Phrase } \\ x & \text { First Argument/Subject Actor/Instrument at Subject } \\ & \\ y \text { sition } & \text { Macrorole Argument of the Verb/Object Undergoer } \\ \mathrm{z} & \text { Intermediary Actor/Causer } \\ \mathrm{j} / \mathrm{k} / \mathrm{i} & \text { Referential Indices }\end{array}$

\section{REFERENCES}

Agyekum, K. 2004. Causativity in Akan. Studies in the Languages of the

Volta Basin II. Proceedings of the Annual Colloquium of the Legon Trondheim

Linguistics Project. Accra: Combert Impressions Limited. pp. 217-227.

Ameka, F. \& Dakubu, K. E. M. 2008. Aspect and modality in kwa languages.

Amsterdam/Philadelphia: John Benjamins Publishing Company.

Boadi, L. A. 2006. Three Major Syntactic Structures in Akan. Accra. Black Mask

Limited. 2010. Akan noun phrase, its structure and meaning. Accra: Black Mash Limited.

Caesar, R. O. 2013. Lexical and Periphrastic Causatives in Dangme. Ph.D Thesis, University of Education, Winneba.

Dakubu, K.M.E. 1966. Ga, Adangme and Ewe (Lomé) with English gloss. Accra: Institute of African Studies, University of Ghana.

De Busser, R. 2010. Beyond the causative continuum. Research Centre for Linguistic Typology (Manuscript).

Dixon, R. M. W. \& Aikhenvald, A. Y. 2000. Changing valency. Case study in transitivity. (eds.) Dixon, R. M. W. \& Aikhenvald, A. Y. Cambridge: Cambridge University Press. pp. 1-29.

Dixon, R.M.W. 2000. A typology of causatives: form, syntax and meaning. In Dixon \& Aikhenvaid (eds) Word: A Cross-Linguistic Typology. Cambridge: Cambridge University Press. pp. 30-83.

Dixon, R.M.W. and Aikhenvald, A.Y. 1997. A typology of argument-determined constructions of essays on language function and language type edited by $\mathrm{J}$. Bybee, J. Haiman and S. Thompson. pp. 71-113. Amsterdam: John Benjamins.

Dryer, M. S. 2005. Clause types. In Clause Structure, Language Typology and Syntactic Description. edited by Timothy Shopen. Vol. 1, p. 728. Cambridge: Cambridge University Press.

Foley, W. A. \& Van Valin, R.. D. (1984). Functional syntax and universal grammar. Cambridge: Cambridge University Press.

Jolly, J. 1991. Prepositional analysis within the framework of Role and Reference Grammar. New York: Lang.

Lyons, J. 1977. Semantic. Vol. 2. New York: Port Chester Melbourn Sydney. Cambridge University Press. 
Rice, K. 2000. Voice and valency in the Athabaskan family. In Changing Valency. Dixon, R.M.W. and Alexandra Y. Aikhenvald, (eds.). Cambridge: Cambridge University Press.

Shibatani, M. 1976. The grammar of causative constructions. A conspectus. syntax and semantics. In the Grammar of Causative Constructions, (ed.) M. Shibatani. New York: Academic Press. Vol. 6:1-40.

Shibatani, M. \& Pardeshi, P. 2000. The causative continuum. The English Biennial Rice University Symposium on Linguistics.

Song, G., \& Wolff, P. 2003. Linking perceptual properties to the linguistic expression of causation. In M. Achard \& S. Kemmer (ed.) Language, Culture and Mind. CSLI Publications. pp. 1-13.

VanValin, R. D. Jr. 2001c. A brief overview of Role and Reference Grammar. available on $R R G$ web site.

Van Valin, R. D., Jr. \& Foley, William A. 1980. Role and Reference Grammar. In Moravcsik and Wirth, (eds.), 329-52.htt://research.omicsgroup.org/index.php./p 